\title{
Pneumococcal Vaccination Challenges in Renal Disease or Renal Transplant
}

\author{
Majid Malaki
}

\section{Majid Malaki}

Pediatric Nephrologist, Sevome Shaban Hospital, Tehran, IRAN.

\section{*Correspondence}

Dr Majid Malaki

Pediatric Nephrologist, Sevome Shaban Hospital, Tehran, IRAN.

Phone: 00989123231477

Email: madjidmalaki@gmail.com

\section{History}

- Submission Date: 21-08-2021;

- Review completed: 24-09-2021;

- Accepted Date: 30-09-2021.

DOI : 10.5530/ijcep.2021.8.3.31

Article Available online

http://www.ijcep.org/v8/i3

\section{Copyright}

(C) 2021 Phcog.Net. This is an openaccess article distributed under the terms of the Creative Commons Attribution 4.0 International license.

\section{Dear Sir,}

There are many challenges to find the best vaccine against pneumococcal bacterial infection due to high incidence of resistance by antibiotic, serotype diversity among patients and technical problems that found after establishing a new vaccine when most prevalent serotypes $35 \mathrm{~B}$ and $23 \mathrm{~A}$ are not included in PPV23 and PCV13 vaccines while serotype 19A is included in both vaccines. ${ }^{[1]}$

The power of immunogenicity of vaccine in special target group such as renal disease partly related to uremia, but the mechanisms of unresponsiveness are multifactorial. ${ }^{[2]}$ It seems that response to pneumococcal vaccine in advanced renal disease and renal transplant patients is unsatisfactory. ${ }^{[3]}$ Pneumococcal vaccines developed successfully from 14 valent pneumococcal in 1977 to 23 valent pneumococcal vaccines in 1983, and conjugated vaccine as a more effective seven valent pneumococcal type vaccine used for children. Pneumococcal vaccines can cover up to $88 \%$ of streptococcus pneumonia pathogenic serotypes but practically in nephrotic syndrome patients with peritonitis, pneumococcal vaccine covered near half of streptococcal pneumonia pathogenic types while all serotypes were susceptible to penicillin. ${ }^{[4,5]}$ Unfortunately, our information about pneumococcal vaccine in renal disease is limited to the selected small sample size with favourable laboratory and clinical condition such as age, serum creatinine in short time of surveillance without control group for comparison and shows that the best immunogenicity can be achieved in 4 weeks (86\%) that remains in $57 \%$ of cases up to 6 months after vaccination. In spite of that the conjugates vaccine type make stronger immunogenicity we cannot find any differences between polysaccharide and conjugate type vaccine to enhance immunogenicity and conjugate vaccine type revaccination make a desirable response shortly that falls rapidly to pre-vaccination period. Such truth is incompatible with American society of nephrology guideline for revaccination of of pneumococcal vaccine every 5 years in renal transplant. ${ }^{[2]}$ In summary, the efficacy of the pneumococcal vaccine in renal disease and renal transplantation is unfavourable based on limited studies, new guidelines based on less biased studies, can establish a more effective vaccination protocol that be addressed for other vaccines.

\section{CONFLICT OF INTEREST}

The author declares no conflict of interest.

\section{REFERENCES}

1. Roca-Oporto C Cebrero-Cangueiro T, Gil-Marqués ML, Labrador-Herrera G, Smani Y, González-Roncero FM et al. Prevalence and clinical impact of Streptococcus pneumoniae nasopharyngeal carriage in solid organ transplant recipients. BMC Infect Dis. 2019;19(1):697. doi: 10.1186/s12879-019-4321-8, PMID 31387529

2. Malaki $M$. Factors affecting on hepatitis $B$ seroprotection in hemodialysis patients. Saudi J Kidney Dis Transpl. 2017;28(3):672-4. doi: 10.4103/1319-2442.206472 PMID 28540917.

3. Fuchshuber $A$, Kühnemund $O$, Keuth $B$, Lütticken $R$, Michalk D, Querfeld U. Pneumococcal vaccine in children and young adults with chronic renal disease. Nephrol Dial Transplant. 1996;11(3):468-73. doi: 10.1093/ oxfordjournals.ndt.a027313, PMID 8671817.

4. Shah A. Pneumococcal vaccine: Vaccinate! Revaccinate? Geriatric Workforce Enhancement Program [cited Aug 02 2019]. Available from: https://www.hopkinsmedicine. org/gec/series/pneumococcal_vaccination.html.

5. Malaker R, Saha S, Hanif M, Ahmed A, Saha S Hasanuzzaman $\mathrm{M}$, et al. Invasive Pneumococcal infections in children with nephrotic syndrome in Bangladesh. Pediatr Infect Dis J. 2019;38(8):798-803 doi: 10.1097/INF.0000000000002386, PMID 31220048.

Cite this article: Malaki M. Pneumococcal Vaccination Challenges in Renal Disease or Renal Transplant. Int J Clin Exp Physiol. 2021;8(3):129. 